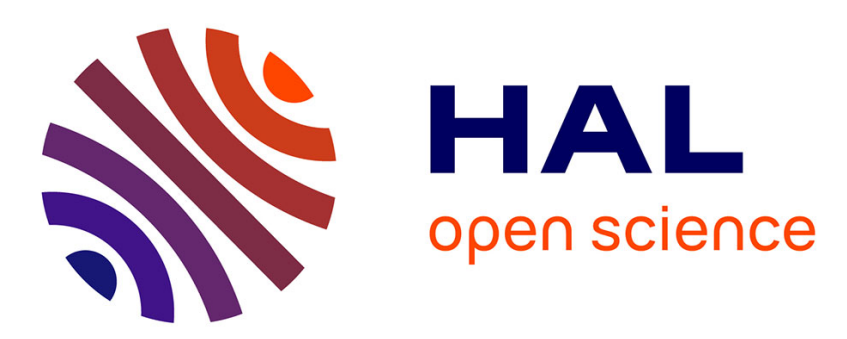

\title{
Some reasons to implement reverse logistics in companies
}

Caroline Rodrigues Vaz, Bernard Grabot, Mauricio Uriona Maldonado, Paulo Mauricio Selig

\section{- To cite this version:}

Caroline Rodrigues Vaz, Bernard Grabot, Mauricio Uriona Maldonado, Paulo Mauricio Selig. Some reasons to implement reverse logistics in companies. International Journal of Environmental Technology and Management, 2013, vol. 16 ( $\mathrm{n}^{\circ}$ 5/6), pp. 467-479. 10.1504/IJETM.2013.059447 . hal01177686

\section{HAL Id: hal-01177686 \\ https://hal.science/hal-01177686}

Submitted on 17 Jul 2015

HAL is a multi-disciplinary open access archive for the deposit and dissemination of scientific research documents, whether they are published or not. The documents may come from teaching and research institutions in France or abroad, or from public or private research centers.
L'archive ouverte pluridisciplinaire HAL, est destinée au dépôt et à la diffusion de documents scientifiques de niveau recherche, publiés ou non, émanant des établissements d'enseignement et de recherche français ou étrangers, des laboratoires publics ou privés. 


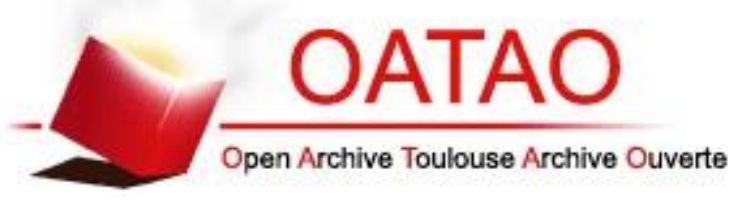

Open Archive Toulouse Archive Ouverte (OATAO)

OATAO is an open access repository that collects the work of Toulouse researchers and makes it freely available over the web where possible.

This is a publisher-deposited version published in: http://oatao.univ-toulouse.fr/ Eprints ID: 10982

Identification number: DOI:10.1504/IJETM.2013.059447

Official URL: http://dx.doi.org/10.1504/IJETM.2013.059447

\section{To cite this version:}

Rodrigues Vaz, Caroline and Grabot, Bernard and Uriona Maldonado, Mauricio and Selig, Paulo Mauricio Some reasons to implement reverse logistics in companies. (2013) International Journal of Environmental Technology and Management (IJETM), vol. 16 ( $n^{\circ}$ 5/6). pp. 467-479. ISSN 1466-2132

Any correspondence concerning this service should be sent to the repository administrator: staff-oatao@inp-toulouse.fr 


\title{
Some reasons to implement reverse logistics in companies
}

\author{
Caroline Rodrigues Vaz*
}

Federal University of Santa Catarina - UFSC,

Campus Universitário Reitor João David Ferreira Lima,

s/n - Trindade Florianópolis - Santa Catarina, 88040-900, Brasil

E-mail: caroline.vaz@posgrad.ufsc.br

*Corresponding author

\section{Bernard Grabot}

University of Toulouse,

ENI de Tarbes,

47, Avenue d'Azereix,

BP 1629 - 65016 Tarbes Cedex, France

E-mail: bernard.grabot@enit.fr

\section{Mauricio Uriona Maldonado and Paulo Mauricio Selig}

Federal University of Santa Catarina - UFSC,

Campus Universitário Reitor João David Ferreira Lima,

s/n - Trindade Florianópolis - Santa Catarina, 88040-900, Brasil

E-mail: m.uriona@ufsc.br

E-mail: selig@deps.ufsc.br

\begin{abstract}
This article aims to present a reflexion on some of the main reasons for companies to implement reverse logistics processes. Companies have difficulties in implementing reverse logistics as part of their business processes due to high cost of implementation and due to difficulties in measuring material returns. However, companies that have succeeded in implementing it have increased their competitiveness and improved their corporate image. This paper proposes six critical success factors for the implementation of reverse logistics: good income control, standardised and mapped processes, reduced time cycle, information systems, planned logistic grid and collaborative relations between customers and suppliers. Well-structured and implemented reverse logistics process brings up benefits and advantages to companies, beyond environmental ones.
\end{abstract}

Keywords: reverse logistics; waste management; implementation process; corporate and social responsibility; environmental management; environmental technology. 
Biographical notes: Caroline Rodrigues Vaz is a $\mathrm{PhD}$ student at the Graduate Program in Production Engineering - UFSC. She holds a Masters in Production Engineering from the Federal Technological University of Parana, Brazil. Her main research interests include reverse logistics and intellectual capital.

Bernard Grabot is a Professor at the Industrial Engineering Department of the National School of Engineers in Tarbes (ENIT - France). His main research interests are on planning and scheduling under uncertainty, competence management, knowledge engineering and industrial information systems.

Mauricio Uriona Maldonado is an Assistant Professor at the Department of Production and Systems Engineering of the Federal University of Santa Catarina (UFSC - Brazil). He is a senior member of the Sustainable Management Research Group (NGS) from UFSC and a research affiliate in innovation processes at Duke University (USA).

Paulo Mauricio Selig is an Associate Professor at the Department of Production and Systems Engineering - UFSC. As former President of the Brazilian Association of Production Engineering, he has a longstanding career in producing and researching performance indicators (tangible and intangible) in his fields of interest: knowledge management, intellectual capital and environmental management.

\section{Introduction}

The concept of corporate logistics or business logistics has gained room in the corporate world by taking into account the management of material, services and information flows. Accordingly, the globalisation of the economy has generated a dynamics in companies as never seen before, producing changes in processes and in customer service (Guarnieri et al., 2006).

Logistics is the management of moving and fixed inventory, where the goal of the logistics manager is to reach the lowest level of consistent inventory investment while offering to consumers and customers adequate service level and keeping adequate production efficiencies (Delaney, 1997).

For Ballou (1993), logistics studies the most effective means by which management provides better profitability levels in materials and product flow to customers and consumers, through planning, organising and performing effective controls of the activities of movement and storage aiming to ease product flow. The challenge of logistics is to balance the expectations of services and expenditures in way to reach business objectives (Bowersox and Closs, 2001).

Reverse logistics appeared as a response to increasing recognition of the environmental impact of the movement of materials, parts, components and supplies and of the need to properly manage them.

Thus, reverse logistics is regarded as the management of material flow from the point of consumption to the point of origin. This inverse flow has grown for the last years due to rise of recycling activities and reuse of products and packages (Guarnieri et al., 2006).

This worldwide trend generated a new profile of consumers that are more concerned and conscious about the environment, aggregating esteem value to ecologically correct products making it one the factors of influence in competitiveness between companies. 
In this context, this article has as objective to present a reflexion on some reasons for companies to implement reverse logistics processes. The work is composed by seven sections, after an introduction, the second section discusses the evolution and definitions of reverse logistics. The third section shows a view of the companies on reverse logistics. The fourth section discusses reasons for companies to implement reverse logistics in their processes. The fifth presents some environmental and economic benefits of companies through reverse logistics, the sixth section listing the critical factors of implementation of reverse logistics.

\section{Reverse logistics}

The first definitions of reverse logistics appeared in the 1990s, as an extension of organisational logistics.

For the Council of Logistics Management (1993), "the field of reverse logistics is broad and related to the skills and activities involved in the management of waste, movement and disposal of products and packages [...]”.

In the same line, the Reverse Logistics Executive Council (2012) states, that reverse logistics refers to the process of planning, implementing and controlling the efficiency and the cost effectiveness of the flow of raw materials, work in process, finished products and all related information, from the point of consumption to the point of origin in order to recapture value or to offer an appropriate disposal.

For the European Working Group on Reverse Logistics (2005), reverse logistics involves all operations related with product and materials reuse as well as the logistics of collection, dismounting and processing of products and used parts with the aim to assure their sustainable recovery without prejudicing the environment.

Reverse logistics is a process of planning, implementation and efficient and at low cost flow control of raw material process stock, finished product and related information, from the point of consumption to the point of origin, with the purpose of value retrieval or appropriate dispose to the collection and treatment of waste (Rogers and Tibben-Lembke, 1999; Sinnecker, 2007).

For Pokharel and Mutha (2009), the focus of reverse logistics is on the management of waste, recycling, and recovery of parts or products (remanufacturing).

Studies in the field of reverse logistics increased in the past years due to the introduction of sustainability in development models (Leite, 2003). The author explains that reverse logistics is concerned with the return of post-sale goods to the business or production cycle by adding value in diverse forms: economic, ecologic, legal, logistic, corporate image, amongst others.

Adlmaier and Sellitto (2007) suggest that reverse logistics can be described as the field of organisational logistics aiming to manage, in an integrated way, all the logistic aspects of the return of goods to the productive cycle, through reverse distribution channels of post-selling and of post-consumption, aggregating their economic and environmental value. Reverse logistics studies the reverse distribution channels; i.e., channels that follow the opposite flow to the original chain of materials, aiming to aggregate value of the return by their reintegration to a point of the productive cycle of origin, or to another productive cycle, as input or raw material. 
Reverse logistics has the function to return products, originated in the reduction, recycling, substitution or reuse of materials, final disposal, repair or remanufacture (Stock, 2001).

De Brito (2004) proposes a structure of implantation of reverse logistics as a whole, as shown in Figure 1.

Figure 1 Basic dimensions of reverse logistics

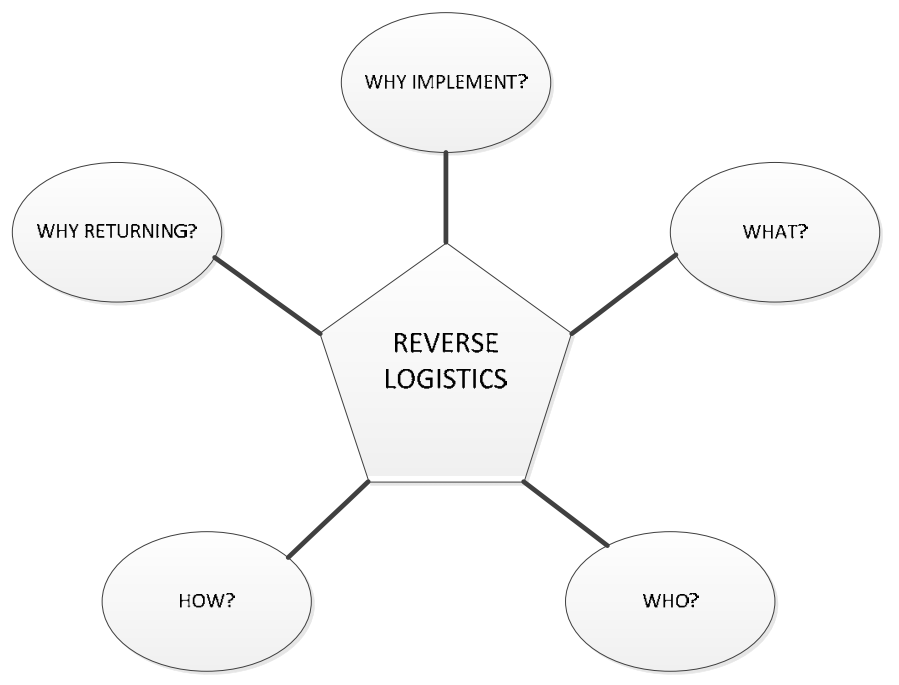

Source: De Brito (2004)

First, the author proposes fundamental and necessary questions for the implantation of reverse logistics, such as:

a why implanting it? - the motivation for companies to get involved with reverse logistics (stimulators)

b why returning? - the reasons why the products are returned (return reasons)

c how? - how the return ins made (process)

d what? - what is being returned (product characteristics and types of products)

e who? - who is making the returns (actors and their roles).

In addition, Giuntini and Andel (1995) present a methodology in five steps or phases for the implementation of a reverse logistics programme:

a the acknowledgement of the need of return of goods

b collection

c decision of which process should be followed (two options: either repair and reuse, where the life cycle of the product will increase, or its disposal, where the condition of the product is not adequate enough)

d performing the process

e re-engineering (analysis of the products to reduce product return in the long term). 
Pokharel and Mutha (2009) propose a process of reverse logistics containing inputs, structure and process, and outputs. In 'structure and process', the authors include the process of collection or gathering, following a process consisting of inspection, selection and classification, including a processing or remanufacturing and finally consolidation, as shown in Figure 2.

Figure 2 Reverse logistics process

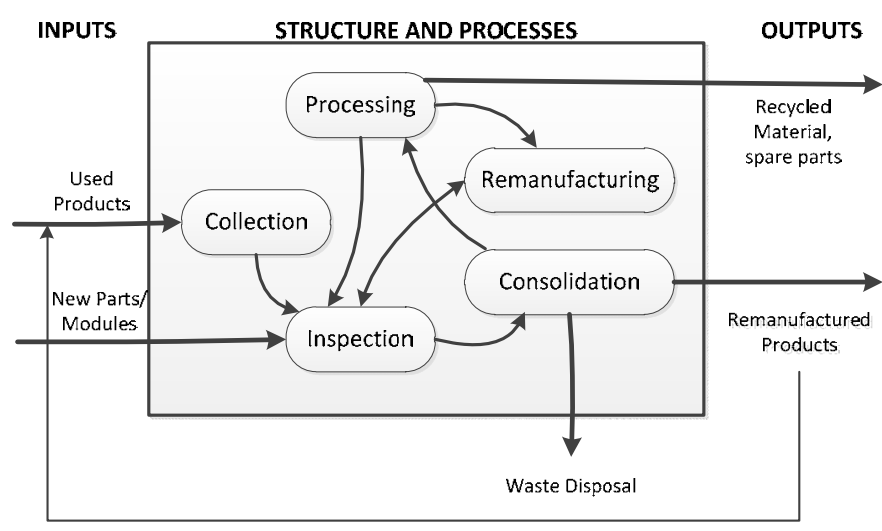

Source: Pokharel and Mutha (2009)

As shown in Figure 2, inputs refer to used products, recycled products or materials, used parts and also to new parts or modules that feed the reverse logistics process. Used products go through the process of collection, by means of designated collection centres or at retailers. New parts go through inspection where they are integrated in used products. In the inspection process, both products (used and new) are segregated to different quality standards in order to make the decision of disposal, minor processing or remanufacturing. Processing of remanufacturing helps in disassembling parts, some of which being marketed to the spare parts market and some others reused. Also, new parts or modules can be needed for remanufacturing when reused parts are in shortage. The outputs of the reverse logistics process are then, recycled products, materials or spare parts and remanufactured products. One last feedback flow is shown in Figure 2, as remanufactured products become inputs as used products to re-start the reverse logistics process.

The processes of reverse logistics exist for a long time, though they were not treated or denominated as such. Currently, there is a constant concern of all companies and public and private organisations, based on four main pillars of sustainability: the awareness raise towards environmental problems; the overcrowding of landfills; the scarcity of raw materials; the policies and environmental laws.

\section{The perspective and views of companies towards reverse logistics}

Companies today acknowledge the importance of the reverse flow, even though there is still a lack of interest and difficulties to implement them (Guarnieri et al., 2006; Quinn, 2001; Rogers and Tibben-Lembke, 1999), due to: 
- lack of computerised systems integrated to management practices, forcing up often the use of traditional logistics systems, or, in the best case scenario, to adapt existing systems to reverse logistics

- the idea that the reverse flow only generates costs, hence, receiving little or no priority in companies

- difficulty in measuring the impact of return of products and/or materials, with the unawareness of the need to control them.

Nevertheless Leite (2005) and Rogers and Tibben-Lembke (1999) stress that it is necessary to consider the reverse flows under the perspective of adding economic value and corporate image to the company. In this way, the management of the reverse channels can serve as a source of information about the expectations and behaviour of customers, propitiating for the company to deliver differentiated services, visible to the customer's eye (Leite and Brito, 2003).

According to Hernández (2010) and Stock (2001) the objective of corporate image gains is assigned as a priority goal in the majority of reverse logistics programmes, because this image is a set of attributes that differentiate a product of a company with the ones from their competitors, by complying with:

- ecologic objectives that show concern with the environmental problems, establishing incentives to the recycling and to the design changes to decrease the impacts on the environment

- through expressed legislation enforcing the producers to engage in the collection and destiny of dangerous products

- social objectives in favour of the community, highlighting actions such as donations, job creation, educational and community projects.

On the other hand, the competitive objectives by differentiation of the level of services to the customers are present in two kinds of reverse channels (Hernández, 2010):

1 with regard to the return of post-sale products, the benefits are evidenced by the loyalty of customers, by cost leadership of services and by the corporate image

2 with regard to the return of post-consumption products, the benefits are evidenced by the competitiveness on costing, by saving resources in manufacturing of products and also in the corporate image.

Although the potential of the reverse logistics activity in the economy is environmentally and economically important, the lack of view of the activity as generator of competitive advantage to the companies compromise the structuring and efficiency of these channels (Chaves and Batalha, 2006).

\section{Reasons to implement reverse logistics}

According to Rogers and Tibben-Lembke (1999), the barriers to implement reverse logistics in companies are brought up by manufacturers that do not feel responsible by 
their products (after consumption) and also by the lack of studies by companies of the benefits of reverse logistics for the product life cycle in organisations.

This corroborates with the ideas of Quinn (2001) that state that many producers believe that reverse logistics only presents costs, strengthening the practices of disposal and incinerations with considerable impact for the environment.

According to Leite (2000), reverse logistics has been used as an important tool of competitiveness gain and of consolidation of the corporate image, when inserted in the corporate strategy and, in particular, in environmental marketing strategy, in companies that have privileged a view of organisational responsibility for the environment and for the society. For such, it is required:

a to equate adequately the various aspects involved in the establishment of reverse distribution channels of materials and products of post-consumption

b to establish the adequate partnerships between companies of reverse chains, allowing a better applicability of environmental legislation

c to detect ecological trends of society, that will give support to up-to-date environmental marketing strategies and will add value for the corporate image for organisations.

It is important to stress that acting with environmental responsibility will impact positively the institutional image of companies and, as a consequence, allows the intensifying of new business, with higher possibilities of job generation, service generation and technological development, more visible as well as with a higher awareness of sustained development (Fagundes and Oliveira, 2008).

Leite (2000) considers that there are three main organisational attitudes regarding the environment, observed from a research made by Council of Logistics Management, in the '90s:

a Reactive attitude: characterised by the compliance of laws and regulations, revealing that the impact of its products and processes on the environment are not part of their organisational strategies. To avoid costs of final disposal, the company uses the sale or a simple withdrawal of their products.

b Proactive attitude: companies design specific sectors for equating products that are linked with the environmental management aiming to anticipate to regulations and legislations. Such companies develop their reverse logistics networks avoiding negative impacts of their products to the environment, developing competitive advantage and redesigning their products.

c Value search attitude: companies develop the capacity to add value to their products and services, making them perceptible to customers and to society, by engaging with ethical responsibility with the society and with the environment. Companies in this phase of organisational development show the best performance and, generally, are leaders in their business sectors. They plan their strategies with a holistic view of the new corporate background, obtaining reductions of operational costs, competitiveness gains and reinforcing their corporate image. Their main strategic actions are: incentive to many specialised fields in the conception of reverse distribution networks, of systems of internal recycling and in partnership in reverse chains, amongst others. 
It is imperative to point out that in reverse logistics, companies become responsible to return the products to the company, be it for recycling, or for disposal. Its costing system shall hence acquire a very broad approach; such as is the case of whole-life cost. For Atkinson et al. (2000), this system allows managers to manage the costs from the beginning to the end.

On the other hand, for Horngreen et al. (1997), "the life cycle of a product covers the time since the beginning of R\&D until the end of support to the customer". In reverse logistics, this cycle is extended out, covering also the return of the product to the point of origin. For a better understanding, the environmental and economic benefits of reverse logistics will be shown in following sections.

\section{Environmental and economic benefits for companies through reverse logistics}

According to Stock (1998), logistics’ concern with reverse logistics was focused only with what happened inside logistics itself. Currently, this subject is growing in importance in the process of management of logistics. Companies are specialising in this activity and earn a competitive advantage. Their perspective of business refers to returnable products, recycling and disposal of material. The activities, programmes and processes of reverse logistic have interfaces with many functional fields, including outside the organisation, in manufacturing, marketing, buying, package engineering, each of these fields having an impact on converting resources, generating income and reaching positive goals.

The challenge is then to define an efficient system of reverse logistics, allowing to transform a costly and complex process of return in a competitive advantage (Campos, 2006).

Some examples of competitive advantages that can be obtained by the adoption of policies and instruments of reverse logistics include (Rogers and Tibben-Lembke, 1999; Leite, 2003; Chaves and Martins, 2005; Chaves and Batalha, 2006):

a Environmental restrictions: raising awareness about environmental conservation does not look like a temporary tendency. This factor induces a long-lasting reorientation of production and the consumption that have amidst their premises in the sustainable growth. In this context, logistics has to seek a minimisation of environmental impact, not only on residuals from production and post-consumption, but on the impact along the products life cycle.

b Cost reduction: the reuse of materials and the economy with returnable packages provide earnings that stimulate new initiatives and efforts in development and improvement of processes of reverse logistics. Many industries, such as t the aluminium industry for example, have in disposable packages a source of high quality raw materials that can be processed at lower costs than those that would be possible from industrialisation of bauxite (basic mineral of this industry).

c Competitive reasons: a way of gaining competitive advantage in relation to competition is the guarantee of liberal policies of product return (strategy of minimising the barriers of return in exchange of products) that make customers loyal. In this way, companies that have a well managed process of reverse logistics tend to 
excel in the market, and can better reach the customers and differentiate themselves to the competitors.

d Differentiation in the corporate image: many companies are utilising reverse logistics strategically, positioning themselves as 'citizen-company', contributing with the community and helping less favoured people. The social role is highlighted by the activities of cooperatives of recycling package collectors. With this,

companies acquire a raise of value of the brand and, often, of their products as well.

It is clear that logistics must be considered a strategic field of importance in the success of business in a company, and its dynamic character is an essential condition in the seeking of low cost and of increment of competitiveness making this an activity of constant evolution (Fagundes and Oliveria, 2008).

However, with the development of more severe environmental legislation and the raised awareness of the consumer about the importance of the environment, companies are being forced to rethink their responsibilities about their products after the usage, seeking actions in the reverse logistics (Miguez et al., 2007).

It is worth noting that the legislation itself that regulates the correct way of disposal, has favoured studies looking for a way to seek economic benefits through usage of products and residuals of the productive process, and companies have to decide between using such solutions or incurring high costs linked to the proper garbage disposal (Daher et al., 2003).

\section{Critical factors for reverse logistics}

The decision to make and/or buy is an important matter for the reverse logistics management. According to Lee et al. (2002), it depends on the following factors:

a volume: if the volume of returns is small, there is no big need of utilising service providers

b cost control: if the providers can make a more effective cost control, maybe it is interesting to outsource the reverse logistics or parts of its processes

c process complexity: if the reverse logistics involves a broad variety of aspects such as inspection, testing, repairing, disposal, rework or repackage, it may be interesting to outsource the activity, since reverse logistics is not a core competence of companies.

Chaves (2009) points out that it is important for companies to have information about the process of reverse logistics to their impact in finance, taxation, inventories, sales and marketing. In addition, the author states that the cited factors are evaluated in junction with the capacity of the service provider in delivering secure and accurate information for data control by the employing company.

Moreover, Lacerda (2002) lists six critical success factors for the case of reverse logistics:

1 Good input controls: consists in the identification of the state of the materials to be returned, and with the decision if the material can or cannot be reused. 
According to Rogers and Tibben-Lembke (1999), a good input control is the major critical factor to make all the reverse flow manageable and profitable.

Campos (2006) considers that the main step in reverse logistics is defining the destination of the products with the objective to separate the products that present defects and are not good enough for recycling.

2 Standardised and mapped processes: the shift of focus in reverse logistics, i.e., where it stops being a sporadic and contingent process, and becomes a regular process, that requires adequate documentation through processes mapping and formalisation. Hence, offering the possibility to identify improvement opportunities.

According to Campos (2006), the processes in reverse flow often lack standardisation, by the fact that they are considered sporadic, irregular and contingent. Adequate standardisation and mapping of processes ease decision making and favours all the reverse flow.

3 Reduced cycle time: It is the decrease of time between the identification of recycling needs, disposal and return of the products and their effective processing.

Campos (2006) defines that the cycle time is the period between the beginning and the end of the process of a product, including the decisions about return of the product, movement and processing. The factors that take a lot of time are inefficient input controls, lack of infrastructure (equipment, personnel) dedicated to the reverse flow and lack of clear procedures to handle the 'exceptions', that are very frequent.

4 Information systems: the process of reverse logistics needs the support of information technology (IT), in order to enable the compliance of the requirements necessary for its operation. Among the functionalities required can be listed: trustable and centralised information, tracking, faults evaluation, etc.

For Campos (2006), a good reverse logistics system needs high quality information that allows the tracking of the return, measurement of cycle times, evaluation of the provider's performance. From the processing of this information, it is possible to achieve better performance.

5 Planned logistics network: consists in the adequate logistics infrastructure needed to deal with the flows of used material income and flows of processed material output. It involves installations, systems, and resources (financial, humans and machines), amongst others.

For the implementation of adequate reverse logistics processes, the logistics network must be planned at the level of each partner. The points of collection, the installations of processing and storage, the points of final destination must be chosen to be linked with the available transportation system, in an efficient way (Campos, 2006).

6 Collaborative relations between customers and suppliers: since there is a series of agents involved in the process, many questions related to the level of trust between the involved parts arise. Information such as, stock levels, sales forecasting and restocking times, must be shared amongst the members of the network so that the system works efficiently. 
Moreover, Campos (2006) considers that conflicts between such agents must also be taken into account, since it is common to observe emerging problems related to the responsibilities of each member of the reverse flow.

On the other hand, Lee et al. (2002) state that a well organised logistics programme must be a well-integrated system of the following key elements:

a return merchandise authorisation control process

b transportation control

C work flow control

d structure and equipment configuration

e information system

f communication channel.

However, Gooley (1998) considers that before implanting a programme of reverse logistics, five points must be considered:

1 The company must verify that there is a need of the programme, and which resources it can offer to reverse logistics.

2 The company must decide how to communicate with the customer and what information will be made available.

3 The company must plan and define the reverse logistics operations. It is necessary to define the possibilities of the reverse logistics process that the company has: resell, restore, recycle, repackage, disposal, amongst others.

4 The development of an information system that incorporates the information about the reverse flow is necessary.

5 The company must know the fiscal, financial and refunding implantations of the reverse logistics programme.

To obtain success of implantation of a reverse logistics system in an organisation, a complex project has to be developed, because it is necessary to define and implement a strong integration between the bonds of the supply chain (Chaves, 2009). However, establishing collaborative relations between the agents is not always easy.

\section{Conclusions}

The first conclusion of this work is that reverse logistics is a multifaceted process and that it needs special attention to be managed, as well as additional capabilities than the ones needed in forward or traditional logistics.

From a more theoretical point of view, this article presented a reflection on some of the main reasons for companies to implement reverse logistics, considering both environmental and economic benefits, and also critical success factors that companies should verify when implementing reverse logistics in their system.

The major problems for the implementation of reverse logistics is that companies usually find themselves lacking of computerised integrated systems, that the reverse 
process has a high cost of implantation and that it may be hard to measure its return on investment.

Currently, a well-structured logistics process brings benefits and advantages to companies, with a raise in competitiveness and consolidation of the corporate image, besides the reduction of consumption of natural resources and pollution to the environment.

A future perspective of this work is the analysis of a reverse logistics process in activity, for verifying if the critical factors of success really help, and which are the environmental and economic benefits that it propitiates.

\section{References}

Adlmaier, D. and Sellitto, M.A. (2007) 'Embalagens retornáveis para transporte de bens manufaturados: um estudo de caso em logística reversa', Revista Produção, May-August, Vol. 17, No. 2, pp.395-406, São Paulo.

Atkinson, A.A. et al. (2000) Contabilidade Gerencial, Atlas, São Paulo.

Ballou, R.H. (1993) Logística empresarial: transportes, administração de materiais e distribuição física, Atlas, São Paulo.

Bowersox, D.J. and Closs, D.J. (2001) Logística Empresarial: O Processo de Integração da Cadeia de Suprimento, Editora Atlas S.A., São Paulo.

Campos, T. (2006) Logística reversa: aplicação ao problema das embalagens da CEAGESP, 154f, Dissertação (Mestrado em Engenharia de Transporte), Universidade de São Paulo, São Paulo.

Chaves, G.d.L.D. and Martins, R.S. (2005) 'Diagnóstico da Logística Reversa na Cadeia de Suprimentos de Alimentos Processados no Oeste Paranaense', VIII Simpósio de Administração da Produção, Logística e Operações Internacionais - VIII SIMPOI, São Paulo.

Chaves, G.L.D. (2009) Logística reversa de pós-venda para alimentos derivados de carne e leite: análise dos retornos de distribuição, 302f, Tese (Doutorado em Engenharia de Produção), Universidade Federal de São Carlos.

Chaves, G.L.D. and Batalha, M.O. (2006) 'Os consumidores valorizam a coleta de embalagens recicláveis? Um estudo de caso da logística reversa em uma rede de hipermercados’, Gestão \& Produção, Vol. 13, No. 3, pp.423-434, São Carlos.

Council of Logistics Management (CLM) (1993) Reuse and Recycling Reverse Logistics Opportunities, Council of Logistics Management, Illinois.

Daher, C.E. et al. (2003) Logística reversa: oportunidade para redução de custos através do gerenciamento da cadeia integrada de valor [online] http://www.alfa.br/revista/artigoc4.php. (accesed 13 June 2013).

De Brito, M.P. (2004) Managing Reverse Logistics or Reversing Logistics Management?, 324f, Tese (Doutorado em Gestão da Produção), Erasmus University Rotterdam, Rotterdam.

Delaney, R.V. (1997) CLI'S 8th Annual State of Logistics Report, Remarks to the National Press Club, 5 June, Washington, DC.

European Working Group on Reverse Logistics (2012) Logistics [online] http://www.supplychain.org (accessed July 2012).

Fagundes, A.B. and Oliveira, I.L. (2008) 'A interação de canais logísticos como fator de sustentabilidade econômica e ambiental', Congresso Internacional de Administração, Ponta Grossa.

Giuntini, R. and Andel, T. (1995) Master the Six R's of Reverse Logistics, Part 2, 3rd ed., Atlas, São Paulo.

Gooley, T.B. (1998) 'Reverse logistic: five steps to success', Logistics Management and Distribution Report, Vol. 37, No. 6, pp.49-55. 
Guarnieri, P. et al. (2006) 'WMS - warehouse management system: Adaptação proposta para o gerenciamento da logística reversa', Produção, Vol. 16, No. 1, pp.126-139.

Hernández, C.T. (2010) Modelo de gerenciamento da logística reversa integrado às questões estratégicas das organizações, 173f, Tese (Doutorado em Engenharia Mecânica), Universidade Estadual Paulista, Guaratinguetá.

Horngreen, C.T. et al. (1997) Contabilidade de custos, 11th ed., Pearson Prentice Hall, São Paulo.

Lacerda, L. (2002) 'Logística reversa: uma visão sobre os conceitos básicos e as práticas operacionais’, Revista de Tecnologistica, January, Ano VI, No. 74, pp.46-50, São Paulo.

Lee, J. et al. (2002) 'Critical issues in establishing a viable supply chain/reverse logistic management program', in International Symposium on Electronics and the Environment, IEEE, San Francisco, EUA, May.

Leite, P.R. (2000) Estudo dos Fatores que influenciam o Índice de Reciclagem Efetivo de Materiais em um grupo selecionado de 'Canais de Distribuição Reversos', Atlas, São Paulo.

Leite, P.R. (2003) Logística reversa: meio ambiente e competitividade, Prentice Hall, São Paulo.

Leite, P.R. (2005) 'Logística Reversa e Competitividade empresarial', Revista Tecnologistica [online] http://www.meusite.mackenzie.com.br/pl (accessed January 2012).

Leite, P.R. and Brito, E.Z. (2003) Reverse Logistics of Returned Products: Practices of Firms in Brazil [online] http://www.meusite.mackenzie.com.br/pl (accessed January 2012).

Miguez, E. et al. (2007) 'Impactos ambientais, sociais e econômicos de uma política de logística reversa adotada por uma fábrica de televisão - um estudo de caso', XXVII Encontro Nacional de Engenharia de Produção, Foz do Iguaçu, out.

Pokharel, S. and Murtha, A. (2009) 'Perspectives in reverse logistics: a review', Resources, Conservation and Recycling, Vol. 53, pp.175-182.

Quinn, P. (2001) Don't Get Rear-ended by your Own Supply Chain [online] http://www.idsystem.com/reader/2001/comm010/index.htm (accessed January 2012).

Reverse Logistics Executive Council (2012) Organização sem fins lucrativos para desenvolver as melhores práticas para logística reversa, Reno-Nevada [online] http://www.rlec.org/glossary. htm (accessed August 2012).

Rogers, D.S. and Tibben-Lembke, R.S. (1999) Going Backwards: Reverse Logistics Trends and Practices, University of Nevada, Reno.

Sinnecker, C.A. (2007) Estudo sobre a importância da Logística Reversa em quatro grandes empresas da região metropolitana de Curitiba, Dissertação (Mestrado em Engenharia de Produção e Sistemas), Pontifícia Universidade Católica do Paraná, Curitiba.

Stock, J.R. (1998) Development and Implementation or Reverse Logistics Programs, Council of Logistic Management, USA.

Stock, J.R. (2001) 'The 7 deadly sins of reverse logistics', Material Handling Management, March, Vol. 56, No. 3, Council of Logistic Management, . Cleveland, USA 